\title{
METODE INKUIRI BERBANTUAN MEDIA BENDA KONKRET DALAM MENINGKATKAN HASIL BELAJAR MATEMATIKA SISWA SEKOLAH DASAR
}

\author{
I Kadek Suputra Ekajana1,*, I Gede Sujana² \\ 1,2Sekolah Dasar Negeri 6 Tianyar
}

\begin{abstract}
Abstrak
Penelitian ini bertujuan untuk mengetahui peningkatan hasil belajar Matematika setelah diberikan tindakan berupa Penerapan Metode Inkuiri Berbantuan Media Benda Konkret dalam pembelajaran matematika siswa kelas III Semester 2 dengan jumlah siswa 10 orang, dengan jumlah siswa laki-laki 4 orang dan siswa perempuan 6 orang di SDN 6 Tianyar, Kecamatan Kubu, Kabupaten Karangasem, diantaranya terdapat 5 orang siswa yang mengalami hasil belajar rendah yaitu dibawah standar yang ditetapkan. Data hasil belajar yang telah terkumpul dianalisis dengan metode statistik diskriptif kuantitatif. Hasil penelitian ini menunjukan bahwa dengan penggunaan Metode Inkuiri Berbantuan Media Benda Konkret pada siswa kelas III Semester 2 SDN 6 Tianyar dapat meningkatkan hasil belajar siswa dari rata-rata kelas 50\% (kurang) sebelum tindakan, setelah tindakan pada siklus I rata-rata nilai kelas adalah 54,6\% (cukup). Besar peningkatan sebelum tindakan dan setelah tindakan pada siklus I sebesar 15\% sedangkan nilai rata-rata kelas pada siklus II adalah 73,8,\% (Baik). besar peningkatan dari siklus I dan siklus II sebesar 19,2\% ini menunjukkan ada peningkatan dari siklus I dan siklus II dari kategori cukup menjadi kategori baik.
\end{abstract}

\section{PENDAHULUAN}

Kemajuan ilmu pengetahuan dan teknologi mengalami perkembangan yang sangat pesat. Oleh karena itu, dalam upaya mengantisipasi kemajuan ilmu pengetahuan dan teknologi tersebut sangat diperlukan sumber daya manusia yang sangat berkualitas, sebagai salah satu faktor penentu yang tidak boleh diabaikan. Hal ini sesuai dengan UU No.20 th 2003 yang menyatakan bahwa pendidikan nasional yang berfungsi mengembangkan kemampuan dan membentuk watak peradaban bangsa yang bermartabat dalam rangka mencerdaskan kehidupan bangsa, bertujuan untuk berkembangnya potensi siswa agar menjadi manusia yang beriman dan bertakwa kepada Tuhan Yang Maha Esa, berakhlak mulia, sehat, berilmu, cakap, kreatif, mandiri, dan menjadi warga negara yang demokratis serta bertanggung jawab.

Untuk mencapai tujuan tersebut, maka pendidikan berlangsung seumur hidup dan dilaksanakan di lingkungan keluarga, sekolah, dan masyarakat. Berdasarkan Undang-Undang No.20 Tahun 2003 tersebut, peran tenaga pendidik dalam hal ini guru sangat penting dalam mengembangkan potensi siswa. Potensi siswa dapat berkembang jika potensi yang dimiliki siswa tersebut terus digali dan ditumbuhkembangkan. Untuk itu, guru dituntut mampu menerapkan metode dan menggunakan media yang bisa mengaktifkan siswa. Selain itu guru juga diharapkan mampu memerankan dirinya sebagai motivator dan fasilitator dalam melaksanakan pembelajaran.

Dari hasil observasi, dalam pelaksanaan pembelajaran Matematika kelas III SD Negeri 6 Tianyar realitanya guru belum sepenuhnya bisa mengaktifkan siswa. Di sisi lain guru juga mengalami masalah dalam melaksanakan proses pembelajaran. Berikut adalah beberapa masalah yang dihadapi guru di SD Negeri 6 Tianyar pada kelas III yaitu: (a) siswa cepat bosan mendengarkan penjelasan guru, (b) siswa kelihatan mengerti dengan materi yang disampaikan guru, tetapi saat diberikan pertanyaan siswa mengalami kesulitan dalam menjawan pertanyaan guru, (c) siswa jarang bertanya dalam proses pembelajaran padahal sebenarnya mereka belum paham, dan (d) siswa kurang antusias dalam mengikuti pelajaran. Hal tersebut dikarenakan guru dalam mengajar mata pelajaran Matematika dengan topik pecahan masih menerapkan metode pembelajaran yang bersifat konvesional. Dalam menyampaikan

* Corresponding author.

E-mail Addresses: saputraekajana@yahoo.com (I Kadek Suputra Ekajana), sujanagede@yahoo.com (I Gede Sujana) 
materi pelajaran guru masih menerapkan metode ceramah dengan asumsi bahwa pengetahuan dapat langsung dipindahkan ke pemikiran siswa. Seharusnya guru menyadari cara pembelajaran seperti ini kurang tepat lagi untuk diterapkan.

Untuk meningkatkan minat siswa dalam pembelajaran, guru harus dapat memilih dan menggunakan metode pembelajaran yang tepat dan efektif. Salah satu diantaranya adalah metode inkuiri. Menurut Merdhana (2014) Inkuiri merupakan suatu rangkaian kegiatan pembelajaran yang melibatkan secara maksimal seluruh kemampuan peserta didik untuk mencari dan menyelidiki secara sistematis, kritis, dan logis sehingga mereka dapat menemukan, dan memahami pengetahuanyang diperoleh". Metode inkuiri merupakan salah satu model pembelajaran yang dianggap mampu menumbuhkan minat dan rasa percaya diri siswa Sujana ( 2005) berpendapat, metode inkuiri adalah metode mengajar yang berusaha meletakkan dasar dan mengembangkan cara berfikir ilmiah.

Metode ini bertolak dari pandangan bahwa siswa sebagai subjek dan objek dalam belajar, mempunyai kemampuan dasar untuk berkembang secara optimal sesuai dengan kemampuan yang dimilikinya. Hudoyo (1990) berpendapat bahwa metode inkuiri merupakan suatu cara untuk menyampaikan ide atau gagasan lewat proses menemukan. Peserta didik menemukan sendiri pola-pola dan struktur matematika melalui serentetan pengalaman belajar yang lampau. Metode inkuiri merupakan bagian inti dari kegiatan pembelajaran berbasis kontekstual.,Pengetahuan dan keterampilan yang diperoleh siswa di harapkan bukan hasil mengingat seperangkat fakta-fakta, tetapi hasil dari menemukan sendiri. Metode inkuiri merupakan metode pembelajaran yang berupaya menanamkan dasar-dasar berpikir ilmiah pada diri siswa, sehingga dalam proses pembelajaran siswa lebih banyak belajar sendiri, mengembangkan kreativitas dalam memecahkan masalah Siswa benar-benar ditempatkan sebagai subjek yang belajar.Peranan guru dalam pembelajaran dengan metode inkuiri adalah sebagai pembimbing atau fasilitator (Supriatin, 2013). metode inkuiri merupakan suatu strategi pembelajaran yang memungkinkan para peserta didik untuk mendapatkan jawabannya sendiri (Soewarso, 2000). Metode inkuiri adalah metode pembelajaran yang dalam penyampaian bahan pelajarannya tidak dalam bentuknya yang final, tidak langsung. Hamalik (2008) menyatakan bahwa pembelajaran inkuiri bertujuan mengembangkan tingkat berpikir dan juga keterampilan berpikir kritis siswa dalam memahami permasalahan yang diberikan.

Menurut hasil penelitian Schlenker, dalam Dahlan (1999), ternyata metode pembelajaran inkuiri dapat meningkatkan pemahaman ilmu pengetahuan, daya kreativitas, serta kepandaian mengolah informasi. Demikian pula penelitian sudarsono (2001), menyimpulkan bahwa inkuiri dapat mengimplementasikan active learning methods. Langkah -langkah kegiatan inkuiri dalam Trianto (2002); Secara operasional langkah -langkah metode inkuiri itu ialah sebagai berikut: (1) Mengajukan pertanyaan, (2) Merumuskan hipotesis, (3) Mengumpulkan data, (4) Analisis data, (5) Membuat kesimpulan. Dalam aplikasinya metode tersebut memiliki kelebihan dan kekurangan sebagaimana metode-metode lainnya .

Roestiyah (2001:28) menekankan bahwa metode inkuiri dapat membentuk dan mengembangkan self concept pada diri siswa, sehingga siswa dapat mengerti serta menemukan konsep dasar dan ide-ide yang tertuang dalam bahan bacaan. Melalui metode inkuiri, siswa juga akan terdorong untuk berpikir dan bekerja secara jujur dan terbuka dalam memahami bahan bacaan yang tidak mampu dipahami oleh siswa melalui waktu yang singkat.

Dari masalah-masalah yang dihadapi di SD Negeri 6 Tianyar kelas III pada mata pelajaran Matematika dengan pokok bahasan pengenalan pecahan sederhana berdampak pada rendahnya hasil belajar siswa, yaitu hanya mencapai 50\%. Hasil belajar siswa ini diperoleh dari hasil ulangan harian siswa yang dilakukan pada akhir pokok bahasan. Untuk mengatasi masalah tersebut, maka perlu diadakan upaya inovasi pembelajaran dengan menerapkan pembelajaran yang berpusat pada siswa. Salah satu metode yang diterapkan agar pembelajaran berpusat pada siswa adalah metode inkuiri. Dengan metode inkuiri siswa lebih aktif, karena siswa diberikan kesempatan untuk berpikir dan menemukan sendiri sesuatu melalui pengamatan langsung sehingga siswa akan merasa dirinya yang menemukannya. Sedangkan dalam keterbatasan media guru bisa menggunakan benda konkret yaitu benda-benda berupa biji-bijian, kartu-kartu, alat permainan atau lembar kerja yang dapat dimanipulasi langsung oleh siswa. Dengan adanya solusi ini diharapkan hasil belajar siswa kelas III SD Negeri 6 Tianyar akan mengalami peningkatan.

Bertolak dari uraian di atas, maka penelitian ini mengkaji tentang penerapan Metode Inkuiri Berbantuan Media Benda Konkret untuk meningkatkan Hasil Belajar Matematika pada topik pecahan khususnya bagi siswa kelas III SD Negeri 6 Tianyar Tahun pelajaran 2010/2011. Banyak para ahli yang mengatakan bahwa penguasaan matematika menjadi sangat penting, karena matematika menjadi gerbang untuk menguasai ilmu pengetahuan yang lain.Menurut Soejadi (2000), belajar matematika pada hakikatnya adalah suatu aktivitas mental untuk memahami arti dari struktur-struktur, hubunganhubungan, simbol-simbol, dan manipula sikan konsep-konsep yang dihasilkan kesituasi yang nyata 
,sehingga menyebabkan perubahan. Melalui pembelajaran matematika siswa diharapkan dapat menata nalarnya, membentuk kepribadiannya serta dapat menerapkan matematika dalam kehidupannya seharihari sesuai dengan tujuan matematika itu sendiri.

Subjek penelitian tindakan kelas ini adalah siswa kelas III semester 2 SD Negeri 6 Tianyar tahun pelajaran 2010/2011 dengan jumlah siswa yang diteliti adalah 10 orang yang terdiri dari 6 perempuan dan 4 laki-laki.

\section{METODE PENELITIAN}

Jenis penelitian inin adalah penelitian tindakan kelas (PTK) yang kegiatan penelitiannya dilaksanakan dari tanggal 16 Januari sampai 20 Februari 2011, di SD Negeri 6 Tianyar Kecamata Kubu, Kabupaten Karangasem. Menurut Arikunto, dkk (2009) mendefinisikan bahwa penelitian tindakan kelas merupakan "suatu pencermatan terhadap kegiatan belajar berupa sebuah tindakan, yang sengaja dimunculkan dan terjadi di sebuah kelas bersama". Sedangkan Supardi, dkk (2009) bahwa penelitian tindakan kelas merupakan "suatu pendekatan untuk meningkatkan pendidikan dengan melakukan perubahan ke arah perbaikan terhadap hasil pendidikan dan pembelajaran".

Berdasarkan definisi di atas, dapat disimpulkan bahwa penelitian tindakan kelas merupakan suatu tindakan yang dimunculkan di kelas untuk memperbaiki praktek pembelajaran guna meningkatkan mutu pembelajaran. Rancangan penelitian tindakan kelas ini dilaksanakan dalam 2 (dua) siklus. Setiap siklus menggunakan model pendekatan yang ditemukan oleh Suharsimi, (2009) yang pelaksanaannya terdiri dari 4 tahap yaitu : a. perencanaan, b. tindakan, c. evaluasi, d. refleksi

Siklus ini dapat digambarkan sebagai berikut.

\section{RencanaPenelitian Tindakan KelasSiklus I dan II}

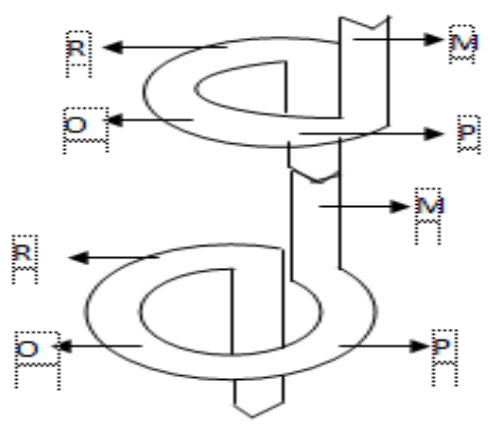

Gambar 1. Diagram Model PTK Kemmis dan MC Taggart (Wardani, 2004 )

Keterangan :

$$
\begin{array}{ll}
\mathrm{M} & =\text { Merencanakan } \\
\mathrm{P} & =\text { Proses Pelaksanaan } \\
\mathrm{O} & =\text { Observasi } \\
\mathrm{R} & =\text { Refleksi }
\end{array}
$$

Adapun instrumen pengumpulan data yang digunakan oleh peneliti untuk memperoleh data yang lengkap dan menghasilkan suatu kesimpulan dalam penelitian ini, digunakan metode sebagai berikut :

Metode tes yang digunakan adalah metode tes uraian (essay). Tes uraian menurut Agung (1999) merupakan "butir tes (soal) yang mengandung pertanyaan atau tugas yang jawaban dan pengerjaan tugas tersebut harus dilakukan dengan cara mengekspresikan pikiran siswa secara tertulis". Alat pengumpulan data berupa butir-butir soal (tes) untuk mengukur Hasil belajar siswa pada mata pelajaran Matematika dalam topik pecahan setelah diterapkan media benda konkret.

Metode observasi adalah "suatu cara memperoleh data dengan jalan mengadakan pengamatan dan pencatatan secara sistematis tenatng suatu objek tertentu", (Agung, 1999). Observasi yang dilakukan adalah observasi berstruktur dan observasi partisipasi. Obervasi dalam hal ini observer ikut berpatisipasi ke dalam situasi lingkungan tempat penelitian dilakukan. Alat pengumpulan data berupa lembar 
observasi yang digunakan untuk mengamati secara langsung tingkat aktivitas siswa di dalam kelas pada mata pelajaran Matematika dalam topik pecahan pada saat penerapan media benda konkret

Data mengenai Hasil belajar siswa diperoleh melalui pemberian tes hasil belajar yang dilakukan pada akhir pertemuan di masing-masing siklus. Jumlah soal tes Hasil belajar adalah sebanyak 20. Bobot skor dari masing-masing soal yang diberikan adalah 1.

Analisis data dalam penelitian ini adalah menggunakan rumus statistik deskriptif kuantitatif. Yaitu "suatu cara pengolahan data yang dilakukan dengan jalan menyusun secara sistematis dalam bentuk angka-angka atau presentase mengenai suatu objek yang diteliti, sehingga diperoleh kesimpulan umum". (Agung, 1999)

Data yang dikumpulkan akan dianalisis dengan menggunakan rumus sebagai berikut. Apabila dalam menghitung rentangan (R) : Skor tertinggi (Xt) dikurangi skor terendah (Xr) ditambah 1, hasilnya lebih kecil dari 15 maka data tersebut dimasukkan ke data tunggal (Sutrisno Hadi, 1986).

Menghitung Mean (Rata-rata)

$$
M=\frac{\sum f X}{N}
$$

(Nurkancana dan Sunartana, 1990)

Keterangan:

$$
\begin{array}{ll}
\mathrm{M} & \text { : Mean/Rata-rata } \\
\sum_{\mathrm{N}} & \text { : Jumlah frekuensi x skor } \\
& \text { : Jumlah subjek }
\end{array}
$$

Untuk mencari presentase digunakan rumus sebagai berikut :

$$
P=\frac{M}{S M I} x 100 \%
$$

(Agung, 1997)

Keterangan:

$$
\begin{array}{ll}
\mathrm{P} & \text { : Persentase } \\
\mathrm{M} & \text { : Skor yang dicapai siswa secara keseluruhan (Mean) } \\
\mathrm{SMI} & \text { : Skor maksimal ideal }
\end{array}
$$

Hasil analisis presentase tingkat Hasil belajar siswa yang diperoleh selanjutnya dikonversikan ke dalam Penilaian Acuan Patokan (PAP) skala lima dengan berpedoman pada kriteria seperti tabel berikut ini

Tabel 1. Kriteria PAP Skala 5 adalah sebagai berikut.

\begin{tabular}{ll}
\hline Presentase & Tingkat Hasil belajar \\
\hline $85 \%-100 \%$ & Sangat Tinggi \\
$70 \%-84 \%$ & Tinggi \\
$55 \%-69 \%$ & Sedang \\
$40 \%-54 \%$ & Rendah \\
$0 \%-39 \%$ & Sangat Rendah \\
\hline
\end{tabular}

(Nurkancana, 1990)

\section{HASIL DAN PEMBAHASAN}

Berdasarkan pelaksanaan proses pembelajaran matematika sub pokok bahasan bilangan pecahan sederhana dengan penerapan metoda inkuiri berbantuan rmedia benda konkrit pada tiap siklus diperoleh hasil sebagai berikut.

Berdasarkan hasil tindakan siklus I data aktivitas belajar Matematika siswa kelas III SDN 6 Tianyar dapat dilihat dalam tabel 2 berikut. 
Tabel 2.

Data Skor Aktivitas Belajar Matematika siswa kelas III SDN 6 Tianyar tahun Pelajaran 2010/2011

\begin{tabular}{|c|c|c|c|}
\hline \multirow{2}{*}{ No } & \multirow{2}{*}{ Kode Siswa } & \multicolumn{2}{|c|}{ Skor Hasil Belajar } \\
\hline & & Siklus I & \multirow[t]{2}{*}{ Siklus II } \\
\hline 1 & 001 & 45 & \\
\hline 2 & 002 & 60 & \\
\hline 3 & 003 & 70 & \\
\hline 4 & 004 & 50 & \\
\hline 5 & 005 & 63 & \\
\hline 6 & 006 & 52 & \\
\hline 7 & 007 & 64 & \\
\hline 8 & 008 & 54 & \\
\hline 9 & 009 & 40 & \\
\hline \multirow[t]{3}{*}{10} & 010 & 48 & \\
\hline & Jumlah & 546 & \\
\hline & kor Rata-rata & 54,6 & \\
\hline
\end{tabular}

Berdasarkan data hasil belajar itu pula dihitung ketuntasan belajanya dengan rumus sebagai berikut

$\mathrm{KB}=$ banyaknya siswa yang memperoleh nilai lebih dari $>55 \times 100$

$K B=\frac{4}{10} \times 100 \%$

$K B=40 \%$

Jadi rata-rata hasil bealajar adalah adalah 54,6, daya serap 54,6 dan ketuntasan belajar siswa adalah $40 \%$

Berdasarkan hasil analisis test belajar didapatakan bahwa rata-rata hasil belar 54,6 sehingga hasil belajar siswa rendah karena belum mencapai ketuntasan belajar minimal yaitu 55. Setelah diadakan repleksi terhadap hasil belajar matematika yang diperoleh diputuskan untuk memperbaiki kelemahankelemahan yang terjadi dalam pembelajaran. Kendala dalam siklus I antara lain:

Dalam perencanaan kegiatan yang dilakukan yaitu membuat silabus menyiapkan rencana pelaksanaan pembelajaran (RPP) sesuai dengan sub pokok bahasan yaitu mengenal bilangan pecahan sederhana, menyiapkan media benda konkrit seperti buah apel, untuk dibagikan pada masing-masing kelompok, menyiapkan alat yang digunakan seperti cutter yang digunakan untuk membagi buah apel yang akan digunakan dalam pengamatan dan menyiapkan tes hasil belajar untuk mengukur kemampuan siswa berupa tes dan lembar observasi. Tes digunakan untuk menilai hasil belajar siswa pada akhir siklus dan lembar observasi digunakan untuk menilai hasil belajar efektif dan psikomotor siswa pada setiap pertemuan.

Pada tahap pelaksanaan, kegiatan pembelajaran dilaksanakan sesuai dengan perencanaan yang telah dibuat sebelumnya. Pelaksanaan tindakan pada siklus 1 terdiri dari pelaksanaan pembelajaran dan pelaksanaan hasil tes belajar.

Pada pelaksanaan pembelajaran terdiri dari 2 kali pertemuan. Materi yang di bahas pada pertemuan pertama adalah mengenal pecahan sederhana dan pada pertemuan kedua materi yang di bahas adalah mengenal lambang pecahan.

Pertemuan pertama membahas materi tentang pengenalan pecahan sederhana .Kegiatan awal yang dilakukan yaitu siswa membagi kelopok yang terdiri dari 5 orang.Setelah kelompok terbentuk,setiap kelompok diberikan LKS (Lembar Kerja Siswa). LKS yang dibagikan berisi tentang langkah-langkah 
pengamatan yang dilakukan. Hasil yang diamati yaitu tentang mengenal pecahan sederhana dari buah apel dan buah jeruk.

Dalam kegiatan pelaksanaan pembelajaran, kegiatan yang dilakukan sesuai dengan langkahlangkah inkuiri yaitu: masing-masing kelompok mengamati media benda konkrit berupa buah apel dan buah jruk yang digunakan dalam pembelajaran pecahan sederhana, siswa di berikan kebebasan untuk mengajukan pertanyaan atau bertanya kepada teman dalam

kelompoknya sehubungan dengan media tersebut, siswa diberikan kesempatan untuk mengajukan dugaan tentang jawaban dari pertanyaan yang muncul dengan mengisi LKS, siswa mengumpulkan data dengan membandingkan bagian-bagian buah yang sudah dibelah menjadi dua bagian sehingga siswa bisa menentukan nilai-nilai pecahan yang dimiliki pada tiap buah apel yang diamati, dan masing-masing kelompok membuat simpulan dari buah apel yang diamati dan siswa menyampaikan hasil dari simpulan yang telah mereka buat ke depan kelas.

Pertemuan kedua,materi yang dibahas adalah mengenal lambang pecahan . Kegiatan awal yang dilakukan yaitu: siswa membentuk kelompok yang tediri dari 5 orang. Setelah kelompok terbentuk ,setiap kelompok diberikan LKS (Lembar Kerja Siaswa). LKS yang dibagikan berisi tentang lankah-langkah pengamatan yang dilakukan. Hal yang diamti yaitu tentang perbandingan dua pecahan yang ada di kelompoknya.

Kegiatan pembelajaran yang dilakukan pada pertemuan kedua sesuai dengan langkah-langkah inkuiri yaitu: siswa mengamati buah jeruk yang dibawa dari rumah,untuk di belah menjadi beberapa bagian untuk diamati, siswa mengajukan pertanyaan sehubungan dengan bagian-bagian buah jeruk yang diamati, siswa mengajukan dugaan-dugaan tentang jawaban dari petanyaan yang muncul dengan menger jakan LKS, siswa mengumpulkan daya dengan membandingkan bagain buah jeruk yang satu dengan bagian yang lainnya, dan siswa maju ke depan kelas untuk menyimpulkan perbandingan dua pecahan termasuk pecahan sederhana.

Dalam pelaksanaan tes hasil belajar pada siklus 1 siswa yang mengikuti tes adalah sebanyak 10 orang siswa. Tes yang diberikan pada siswa merupakan tes pilihan ganda yang harus dikerjakan secara individu bukan kelompok. Dalam mengerjakan tes pilihan ganda, siswa tidak diperbolehkan untuk mencontek jawaban temann. Untuk menghindari adanya siswa yang mencontek jawaban temannya, maka siswa di minta duduk berjauhan dan siswa di awasi secara ketat dalam mengerjakan soal. Hal ini di lakukan untuk mengetahui sejauh mana kemampuan siswa dalam memahami materi yang telah disampaikan

Untuk mengetahui data tentang data siswa, digunakan metode tes yaitu berupa pilihan ganda yang dilaksanakan pada akhir siklus. Jumlah soal pada tes pilihan ganda yaitu 20 butir soal dengan bobot soal 1 . Jadi sekor maksimal ideal untuk soal yang disajikan adalah 20.

Berdasarkan hasil pengumpulan data dengan menggunakan metode tes tersebut maka dapat disajikan data tentang hasil belajar kognitif siswa dalam sub pokok bahasan pecahan sederhana pada siklus I. Data tentang hasil kognitif belajar siswa tersebut kemudian dianalisis menggunakan rumus:

Tingkat ketuntasan individual

Untuk menghitung ketuntasan secara individual yang diperoleh digunakan rumus:

$$
\text { Nilai }=\frac{\sum \text { Skoryangdicapaisiswa }}{\text { SkorMaksimal }} \times 100 \text { (Nurkancana dan Sunartana, 1990) }
$$

Dari tingkat ketuntasan individual yang diperoleh pada siklus 1 itu dapat di lihat tabel IV.01

Berdasarkan pada tabel IV.01 maka dapat diketahui bahwa jumlah siswa yang memperoleh nilai < 55 adalah sebanyak 6 orang dan jumlah siswa yang memperoleh nilai $>55$ adalah 6 orang

Berdasarkan Berdasarkan analisis test belajar didapatakan bahwa rata-rata hasil belar 54,6 sehingga hasil belajar siswa rendah karena belum mencapai ketuntasan belajar minimal yaitu 55siklus 1 , diketahui hasil belajar siswa belum memenuhi kriteria ketuntasan yang telah ditetapkan. Untuk itu proses pembelajaran dilanjutkan pada siklus II. Pada siklus 1 terungkap beberapa kendala yang dialami dalam melaksanakan proses pembelajaran dengan menerapkan metode inkuiri berbantuan media benda konkrit. Kendala-kendala yang dialami selama penerapan metode inkuiri berbantuan media benda konkrit dalam pelaksanaan pembelajaran siklus 1 adalah sebagai berikut, pertama Siswa kelihatan bingung dalam melakukan pengamatan sehingga siswa sering mengganggu temannya dan bercanda, kedua Siswa tidak terbiasa melakukan kerja ilmiah sehingga belum memahami apa yang diharapkan melalui kegiatan menemukan sendiri. Ketiga Siswa kurang termotivasi untuk menjawab pertanyaan dan mengungkap pendapat dalam kelompok. Keempat Siswa kurang aktif berpartisivasi dalam mengikuti proses pembelajaran. Kelima Suasana pembelajaran yang kurang kondusip karena siswa merasa bosan mengikuti pelajaran dikelas. 
Kendala-kendala yang dihadapi selama siklus1 ini, dipergunakan sebagai acuan untuk melaksanakan perbaikan pada pembelajaran siklus 2 .

Berdasarkan hasil siklus 1 diketahui bahwa hasil belajar pada siklus 1 dapat dikatakan belum tuntas secara klasikal, maka desain pembelajaran pada siklus 1 perlu diperbaiki agar hasil pada siklus II lebih baik. Adapun perbaikan proses pembelajaran yang dilakukan pada siklus 2 sebagai berikut, 1) Berkeliling dari satu kelompok ke kelompok lain untuk memberi arahan kepada siswa, 2) Memberi lembar kerja siswa sebelum dilakukan kegiatan belajar mengajar agar dapat dipelajari sebelumnya. 3) Memberi arahan kepada siswa tentang kerja ilmiah sehingga siswa dapat memahami apa yang diharapkan melalui kegiatan menemukan sendiri. 4) Memotivasi siswa untuk menjawab pertanyaan dan mengungkapkan pendapat dalam kelompok. 5) Menegur siswa yang bercanda dan mengganggu temannya.

Dalam perencanaan siklus II kegiatan yang dilakukan yaitu membuat silabus, menyiapkan rencana pelaksanaan pembelajaran berbasis inkuiri yang merupakan perbaikan dari siklus 1 , menyiapkan alat berupa cutter yang digunakan dalam mengamati buah apel, dan menyediaka tes hasil belajar untuk mengukur kemampuan siswa berupa tes dan lembar observasi. Tes yang digunakan untuk menilai hasil belajar siswa pada akhir siklus dan lembar observasi digunakan untuk belajar afektif dan psikomotor siswa pada setiap pertemuan.

Tabel 3. Data hasil Belajar

\begin{tabular}{cccc}
\hline \multirow{2}{*}{$\mathrm{N}$} & \multirow{2}{*}{ Kode Siswa } & \multicolumn{2}{c}{ Skor Hasil Belajar } \\
\cline { 3 - 4 } 2 & & 45 & Siklus I \\
3 & 001 & 60 & 80 \\
4 & 002 & 70 & 85 \\
5 & 003 & 50 & 80 \\
6 & 004 & 63 & 50 \\
6 & 005 & 52 & 80 \\
7 & 006 & 64 & 80 \\
8 & 007 & 54 & 80 \\
\hline 9 & 008 & 40 & 53 \\
0 & 009 & 48 & 80 \\
\hline & 010 & 546 & 738 \\
\hline
\end{tabular}

Pada tahap pelaksanaan, kegiatan pembelajaran dilaksanakan sesuai dengan perencanaan yang telah dibuat sebelumnya. Pelaksanaan tindakan pada siklus II terdiri dari pelaksanaan pembelajaran dan pelaksaan tes hasil belajar.

Pelaksanaan pembelajaran pada siklus II dilaksanakan dalam dua kali pertemuan, pertemuan pertama membahas materi tentang perbandingan pecahan dan pada pertemuan kedua membahas materi tentang memecahkan masalah yang melibatkan pecahan.

Pertemuan pertama, kegiatan pembelajaran yang dilakukan pada pertemuan pertama sama seperti yang dilakukan pada proses pembelajaran siklus I. Perbedaannya pada siklus II kegiatan pelaksanaan pembelajaran dilakukan diluar kelas. Siswa diberikan kebebasan untuk menentukan tempat dalam melakukan pengamatan. Pada kegiatan awal siswa dibagi menjadi dua kelompok stiap kelompok terdiri dari 5 orang. Setelah kelompok terbentuk, setiap kelompok diberikan lembar kerja siswa (LKS). LKS yang dibagikan pada masing-masing kelompok berisi tentang langkah-langkah pengamatan yang harus dilakukan. Hal yang diamati yaitu dua jenis buah yang ada dalam kelompoknya. 
Pada kegiatan pelaksaan, kegiatan yang dilakukan sesuai dengan langkah-langkah inkuiri yaitu siswa mengamati dua buah apel yang ada dalam kelompoknya untuk membandingkan pecahan, siswa diberikan kebebasan untuk mengajukan pertanyaan atau bertanya pada teman dalam kelompoknya sehubungan dengan buah yang diamati, siswa diberikan kesempatan untuk mengajukan dugaan tentang jawaban dari pertanyaan yang muncul dengan mengisi LKS, siswa mengumpulkan data dengan membandingkan antara buah yang satu dengan buah yang lainnya sehingga siswa bisa membandingkan pecahan yang dimiliki oleh setiap buah yang diamati, setiap kelompok membuat simpulan dari buah yang diamati dan salah satu siswa yang ditunjuk guru menyampaikan hasil dari simpulan yang telah mereka buat.

Pertemuan kedua, materi yang dibahas adalah pemecahan masalah yang melibatkan pecahan. Kegiatan awal yang dilakukan pada pertemuan kedua sama dengan kegiatan awal yang dilakukan pada pertemuan pertama.

Kegiatan pembelajaran yang dilakukan pada pertemuan kedua sesuai dengan langkah-langkah inkuiri yaitu siswa mengamati buah apel dan buah jeruk yang mereka bawa dari rumah untuk membandingkan pecahan dan memecahkan masalah yang melibatkan pecahan, siswa mengajukan pertanyaan sehubbungan dengan buah yang mereka amati, siswa mengajukan dugaan-dugaan tentang jawaban dari pertanyaan yang muncul dengan mengerjakan LKS, siswa menngumpulkan data dengan membandingkan buah yang satu dengan buah yang lainnya, dan salah satu siswa ditunjuk guru maju ke depan kelas untuk menyimpulkan bagian-bagian yang dimiliki buah apel dan buah jeruk.

Dalam pelaksanaan tes hasil belajar pada siklus I siswa yang mengikuti tes adalah sebanyak 10 orang. Tes yang diberikan kepada siswa merupakan tes pilihan ganda yang harus dikerjakan secara individu bukan kelompok. Dalam mengerjakan tes pilihan ganda, siswa tidak diperbolehkan untuk mencontek jawaban teman. Untuk menghindari siswa yang mencontek jawaban temannya, maka siswa diminta duduk berjauhan dan siswa diawasi secara ketat dalam mengerjakan soal. Hal ini dilakukan untuk mengetahui sejauh mana kemampuan siswa dalam memehami materi yang telah disampaikan.

Dalam tahap observai dan evaluasi yang dinilai yaitu hasil belajar kognitif, hasil belajar afektif, dan hasil belajar psikomotor siswa.

Data hasil belajar kognitif sisswa pada siklus II dikumpulkan melalui metode tes berupa tes pilihan ganda yang dilaksanakan pada akhir siklus. Jumlah soal pada tes pilihan ganda yaitu 20 butir dengan bobot setiap soal satu, jadi skor maksimal ideal untuk soal yang disajikan adalah 20. Skor hasil tes siklus II yang diperoleh siswa dianalisis menggunakan rumus,

Tingkat Ketuntasan Idividual

Untuk menhitung tingkat ketuntasan secara indivudual digunakan rumus :

$=\frac{\sum \text { Skoryangdicapaisiswa }}{\text { Skormaksimal }} \times 100$

Hasil tingkat ketuntasan individual yang diperoleh pada siklus II ini dapat dilihat pada Tabel 4.

Tabel .4 Data ketuntasan individu hasil belajar kognitif siswa pada siklus II

\begin{tabular}{cccc}
\hline No & Nilai & Banyaknya siswa & Keterangan \\
\hline 1 & Nilai $<55$ & 2 orang & Tidak tuntas \\
2 & Nilai $>55$ & 8 orang & Tuntas \\
\hline
\end{tabular}

Berdasarkan data pada tabel IV.03 maka dapat diketahui bahwa siswa yang memperoleh nilai $<55$ adalah senbanyak 2 orang dan jumlah siswa yang memperoleh nilai >_55 adalah sebanyak 8 orang. Tingkat Ketuntasan Klasikal. Untuk menghitung tingkat ketuntasan klasikal dicari dengan menggunakan rumus:

KK=Jumlah siswa yang memperoleh nilai >_60 X $100 \%$

Banyaknya siswa yang mengikuti tes

$$
\begin{aligned}
& =8 / 10 \times 100 \% \\
& =80 \%
\end{aligned}
$$

Hasil tingkat ketuntasan klasikal yang telah dicapai pad siklus II yaitu 80\% . Apabila dibandinngkan dengan kriteria PAP skala lima ternyata berda pada kategori $80 \%-100 \%$. Hal ini bearti bahwa hasil belajar kognitif sioswa dalam sub pokok pecahan sederhana dan lammbangnya berada pada kategori baik. 
Untuk data rekapitulasi hasil belajar kognitif siswa pada sub pokok bahasan perbandingan pecahan dan memecahkan masalah yang melibatkan pecahan yang telah dicapai pada masing-masing siklus pada dilihat pada tabel 5

Tabel 5 Rekapitulasi hasil belajar kognitif yang dicapai siswa

\begin{tabular}{|c|c|c|c|}
\hline \multirow[t]{2}{*}{ No } & \multirow[t]{2}{*}{ Keterangan } & \multicolumn{2}{|c|}{ Hasil belajar kognitif } \\
\hline & & Siklus I & Siklus II \\
\hline 1 & Nilai $<55$ & 6 orang & 2 orang \\
\hline 2 & Nilai $>55$ & 4 orang & 8 orang \\
\hline 3 & Ketuntasan Klasikal (KK) & $40 \%$ & $80 \%$ \\
\hline 4 & Kategori & Kurang baik & Sangat Baik \\
\hline
\end{tabular}

Dari Tabel 5 menujukan bahwa pada siklus 1 ketentuan klasikal yang dicapai sebesar 0\% dengan kategori cukup dan pada siklus II ketuntasan klasikal yang dicapai sebesar 80\% dengan kategori sangat baik. Hal ini menunjukkan terjadi peningkatan hasil belajar kognitif siswa dari cukup pada siklus I menjadi kategori sangat baik pada siklus II.

Berdasarkan rekapitulasi hasil belajar kognitif siswa yang disajikan pada Tabel IV.05 maka data tersebut dapat disajikan dalam bentuk grafik batang sebagai berikut.

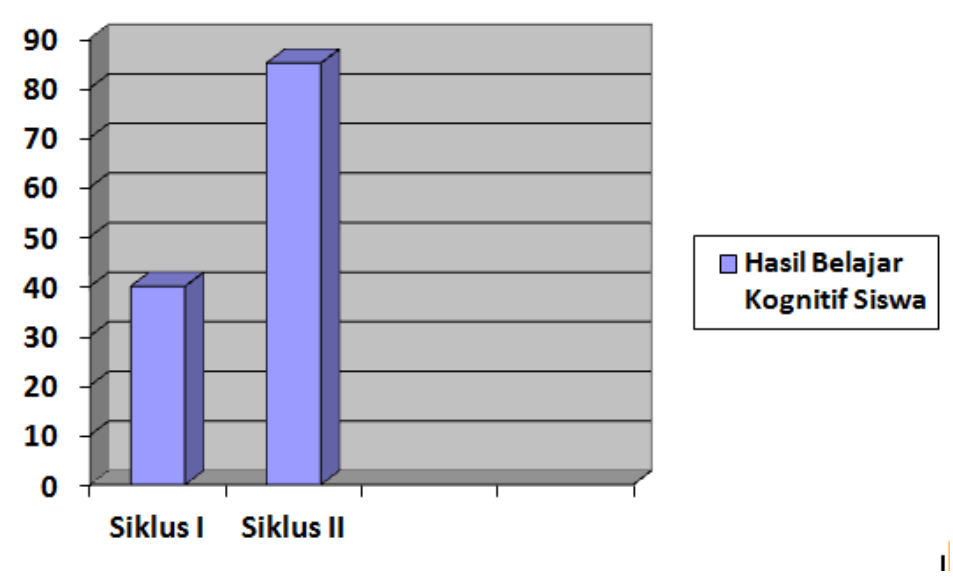

Gambar 2. Grafik Batang hasil belajar kognitif siswa

Berdasarkan hasil analisis siklus II , maka dapat diketahui telah terjadi peningkatan hasi belajar siswa dibandingkan dengan siklus I. Peningkatan yang tercapai pada siklus II terjadi karena telah dilakukan perbaikan proses pembelajaran yang membuat siswa lebih termotivasi, disiplin dan aktif, dalam menguikuti proses pembelajaran. Pada siklus II, secara klasikal hasil belajar sisiwa telah memenuhi kriteria ketuntasan klasikal sehingga pembelajaran tidak dilanjutkan pada siklus selanjutnya.

Beberapa hal yang dapat dijadikan refleksi terkait dengan proses penilaian dalam pembelajaran pada siklus II yaitu : 1) Keberanian siswa dalam mengemukakan pendapat dan menjawab pertanyaan sudah meningkat walaupun masih ada beberapa siswa yang tidak dapat mengemukakan pendapatnya. 2) Kerjasama siswa meningkat. Hal ini terlihat pada saat melakukan percobaan dan diskusi kelompok. Anggota kelompok terlihat aktif baik dalam melakukan percobaan maupun dalam melakukan diskusi. 3) Kedisiplinan siswa dalam proses pembelajaran sudah meningkat. Dalam proses pembelajaran siswa sudah bisa tertib, walaupun ada beberapa siswa yang masih mengganggu temannya.

Berdasarkan hasil ulangan pada pokok bahasan mengenal pecahan sederhana dan penggunaan pecahan sebelum diterapkan metode inkuiri bermedia benda konkrit ternyata hasil belajar siswa belum memenuhi tingkat ketuntasan klasikal. Hal ini dapat diketahui dari nilai ketuntasan klasikal prasiklus yang masih cenderung rendah yaitu 50\%. Padahal nilai KKM untuk mata pelajaran Matematika yang harus dipenuhi oleh setiap siswa adalah 60. Nilai siswa yang belum memenuhi KKM disebabkan oleh cara 
mengajar guru yang masih menerapkan metode ceramah. Menurut Dimyanti \& Mudjiono (dalam Wirawan, 1999: 21) guru hendaknya tidak lagi mengajar sekedar sebagai kegiatan menyampaikan pengetahuan, keterampilan dan sikap pada siswa. Guru hendaknya mengajar untuk membelajarkan siswa dalam konteks belajar bagaimana belajar mencari, menemukan, dan meresapkan pengetahuan, keterampilan, dan sikap. Untuk itu, guru hendaknya dapat menerapkan metode pembelajaran yang dapat mengaktifkan siswa. Selain metode pembelajaran, penggunaan media dalam mengajar juga harus diperhatikan. Tetapi realitanya guru kelas III SD Negeri Tianyar pada saat mengajar Matematika tidak menggunakan media dalam mengajar subpokok bahasan pengenalan pecahan. Para guru dapat memanfaatkan media benda konkrit berupa buah apel dan jeruk dalam mengajar subpokok bahasan pengenalan pecahan . Dengan menggunakan media benda konkrit dapat menarik minat belajar siswa. Hal ini diungkapkan oleh Sumantri \& Johar (1999: 202) bahawa media benda konkrit merupakan benda yang sebenarnya dan cenderung dapat menarik minat belajar siswa. Bertolak dari kondisi awal tersebut dilakukan penelitian tindakan kelas untuk mengoptimalkan hasil belajar siswa melalui penerapan metode inkuiri berbantuan media benda konkrit dalam subpokok bahasan pengenalan pecahan.

Hasil tes kognitif siswa pada siklus I dengan metode inkuiri berbantuan rmedia benda konkrit ratarata skor siswa yang tuntas atau mendapat nilai $>60$ adalah sebanyak 6 orang siswa dengan tingkat ketuntasan belajar sebesar 60\%. Hal ini berarti bahwa 4 siswa memperoleh nilai dibawah 60. Dari tingkat ketuntasan klasikal 60\% menunjukkan pengetahuan siswa tentang materi pengenalan pecahan masih minim atau belum optimal. Pada siklus I untuk hasil belajar kognitif siswa apabila dibandingkandengan kriteria PAP skala lima berada pada dikatagorikan cukup.

Peningkatan hasil belajar yang dianggap masih belum optimal pada siklus I ini terjadi karena adanya kendala-kendala yang dialami dalam melaksanakan proses pembelajaran dengan menerapkan metode inkuiri berbantuan media benda asli. Adapun kendala-kendala yang dialami selama menerapkan metode inkuiri berbantuan media benda asli adalah : 1) Siswa masih kelihatan bingung dalam melakukan pengamatan, sehingga siswa sering mengganggu temannya dan bercanda, 2) Siswa tidak terbiasa untuk melakukan kerja ilmiah sehingga belum memahami apa yang diharapkan melalui kegiatan menemukan sendiri, 3) Dari kendala-kendala yang dialami pada siklus I maka pada siklus II dilakukan perbaikan proses pembelajaran agar pada siklus II terjadi peningkatan yang optimal.

Untuk hasil observasi afektif dan psikomotor siswa pada siklus I belum memenuhi kriteria yang diharapkan. Pada siklus I, hasil belajar afektif siswa yaitu sebesar 60\% dengan kategori cukup sedangkan untuk hasil belajar psikomotor siswa yaitu 50\% dengan kategori kurang. Hasil yang belum memenuhi harapan tersebut karena sebagian besar siswa tidak mau terlibat aktif berpartisipasi dalam mengikuti proses pembelajaran, sebagian siswa yang mengganggu temannya saat kerja kelompok, siswa kurang termotivasi untuk menjawab pertanyaan dan mengungkapkan pendapat dalam kelompok, suasana pembelajaran yang kurang kondusif karena siswa merasa bosan mengikuti pembelajaran di kelas.

Pada siklus II hasil tes kognitif siswa ternyata terjadi peningkatan yang berada pada kategori tinggi dengan sangat baik ketuntasan klasikal sebesar 80\%. Hal ini berarti bahwa 8 orang siswa memperoleh nilai > 55 dan hanya 2 orang siswa yang memperoleh nilai < 55. Dari data tersebut dapat disimpulkan bahwa penerapan metode inkuiri berbantuan media benda konkrit dapat meningkatkan hasil belajar kognitif siswa dalam pokok bahasan pengenalan pecahan dan penggunaan pecahan.

Peningkatan yang terjadi pada siklus II karena kendala-kendala yang dialami dalam melaksanakan proses pembelajaran dengan menerapkan metode inkuiri berbantuan media benda konkrit telah ditanggulangi dan diperbaiki. Perbaikan yang dilakukan dalam proses pembelajaran yaitu : 1) Berkeliling dari satu kelompok ke kelompok lain untuk memberi arahan kepada siswa yang kelihatan agak bingung. 2) Memberikan lembar kerja siswa sebelum dilakukan kegiatan belajar mengajar agar dapat dipelajari sebelumnya. 3) Memberi arahan kepada siswa tentang kerja ilmiah sehingga siswa dapat memahami apa yang diharapkan melalui kegiatan menemukan sendiri.

Untuk hasil belajar afektif dan psikomotor siswa pada siklus II dapat dikategorikan sangat aktif. Hal; ini terjadi karena telah dilakukan perbaikan proses pembelajaran. Perbaikan proses pembelajaran pada siklus II yaitu :1) Memotivasi siswa untuk menjawab pertanyaan dan mengungkapkan pendapat dalam kelompok. 2) Menegur siswa yang bercanda dan mengganggu temannya. 3) Tidak selalu melakukan percobaan di dalam kelas, tetapi diberikan suasana baru dengan mengajak siswa melakukan percobaan diluar kelas.

Pencapaian hasil belajar afektif dan psikomotor siswa pada siklus II telah memenuhi kriteria yang telah ditetapkan jika dibandingkan dengan hasil belajar pada siklus I dan sebelum tindakan. Peningkatan hasil belajar pada siklus II tersebut terjadi karena pada siklus II telah diadakan perbaikan pembelajaran dan kekurangan-kekurangan yang ditemukan pada siklus I telah diatasi. 


\section{KESIMPULAN DAN SARAN}

Berdasarkan hasil analisis data dan pembahasan yang telah disajikan dalam Bab IV, maka dapat ditarik kesimpulan bahwa. Penerapan media benda konkret dalam proses pembelajaran dapat meningkatkan Hasil belajar Matematika pada topik pecahan siswa kelas III SD Negeri 6 Tianyar Semester II dengan perolehan angka rata-rata Hasil kelas pada siklus I sebesar 65\% berada pada kategori sedang. Sedangkan pada siklus II sebesar 83\% berada pada kategori tinggi. Dengan demikian, dari siklus I ke siklus II mengalami peningkatan sebanyak $18 \%$.

Penerapan media benda konkret ternyata sangat efektif dalam meningkatkan Hasil belajar Matematika khususnya pada pokok bahasan pengenalan pecahan sederhana siswa kelas III SD Negeri 6 Tianyar Kecamatan Kubu Kabupaten Karangasem tahun pelajaran 2010/2011.

Bertitik tolak dari simpulan di atas, maka dapat dijadikan saran-saran sebagai berikut. 1) Kepada seluruh siswa kelas III SD Negeri 6 Tianyar agar dalam proses pembelajaran yang menggunakan media benda konkret selalu mengikuti dan memperhatikan dengan sungguh-sungguh sehingga dapat menguasai materi pelajaran dengan baik. 2) Kepada guru-guru pengajar bidang studi Matematika di Sekolah Dasar agar dalam mengelola proses pembelajaran perlu mencoba menerapkan media benda konkret sehingga dapat keterampilan proses dan Hasil belajar Matematika khususnya pada pokok bahasan pengenalan pecahan sederhana pada siswa. 3) Kepada Kepala Sekolah disarankan agar dapat menciptakan kondisi yang mampu mendorong para guru untuk mencoba menerapkan media benda konkret dalam pembelajaran Matematika khususnya dan bidang studi lain pada umumnya.4) Kepada peneliti lain yang berminat untuk mengadakan penelitian lebih lanjut mengenai penerapan media benda konkret pada bidang ilmu Matematika maupun bidang ilmu lainnya yang sesuai, agar penelitian ini dapat dijadikan acuan atau referensi demi ketuntasan penelitian selanjutnya dan memperhatikan kendala-kendala yang peneliti alami sebagai bahan pertimbangan untuk perbaikan dan menyempurnakan pelaksanaan penelitian

\section{DAFTAR PUSTAKA}

Agung, A.A. G. 1999. Metodologi Penelitian Pendidikan. Singaraja. STKIP Singaraja

Ali, 1992 ; 89 Strategi Belajar Mengajar Bahasa Indonesia

Arikunto, Suharsimi, dkk. 2009. Penelitian Tindakan Kelas. Jakarta : Bumi Aksara

Aryati, Luh. 2003. Penggunaan Media Benda Konkret untuk Meningkatkan Hasil Belajar dalam Pembelajaran Matematika pada Siswa Kelas I Semester I di SD No. 3 Sidatapa Kecamatan Banjar Singaraja. Skripsi

(Tidak Diterbitkan). Institut Keguruan dan Ilmu Pendidikan Negeri Singaraja. Bandung: Pustaka Setia

Dahlan. 1999. Model-Model Mengajar. Bandung Diponegoro.

Depdikbud, 2005: Pengelolaan Bagi Guru Mata Pelajaran .

Hamalik, Oemar. (2008). Kurikulum dan Pembelajaran. Jakarta : PT. Bumi Aksara.

Hudoyo, Herman. (1990). Strategi mengajar belajar IPA, Malang : IKIP Malang.

Imbrahim dan Syiadil. 1993. Perencanaan Pengajaran. Jakarta: Depdikbud Dirjen Dikti Jakarta : Direktorat Pendidikan Menengah Umum Jakarta:Prestasi pustaka.

Merdhana, Dkk. 2014. Penerapan Metode Inkuiri Untuk Meningkatkan Aktivitas Dan Hasil Belajar Membaca Pemahaman Siswa Kelas Xi.Ips2 Sma Negeri 2 Mengwi. E-Journal Pend. Bhs Dan Sastra Indonesia Universitas Pendidikan Ganesha Pend. Bahasa Dan Sastra Indonesia (Volume : Vol: 2 No:1Tahun:2014).http://download.portalgaruda.org/article.php?article $=145810 \& v a l=1349 \&$ titl e=Penerapan \%20metde\%20inkuiri\%20untuk\%20peningkatan\%20aktivitas\%20dan\%20hasil\% 20belajar\%20membaca\%20pemahaman\%20siswa\%20kelas\%20xi\%20ips.2\%20sman\%202\%20 mengwi. 
Nurkencana, Wayan dan Sunartana. 1990. Evaluasi Hasil Belajar. Surabaya : Usaha Nasional

Purwanto, Metedeologi Penelitian Pendidikan. Surabaya: SIC

Rusyan, A. Tabrani. 1993. Proses Belajar Mengajar yang Efektif Tingkat Pendidikan Dasar. Bandung : Bina Bhudaya

Roestiyah, 2001. Strategi Belajar Mengajar. Jakarta: Rineka Cipta.

Setiadi, 2003:7. Implementasi pembelajaran dengan pendekatan bernabtuan LKS kontekstual sebagai upaya untuk meningkatkan konsep diri dan kompetensi dasar matematika kelas siswa kelas VIIIA SMP N 4 Singaraja tahun ajaran 2005/2006.Undiksha Singaraja.

Soedjadi R. (2000). Kiat Pendidikan Matematika di Indonesia, (konstatasi keadaan masa kini menuju harapan masa depan).Jakarta: Direktorat Jenderal Pendidikan Tinggi. Depdiknas.

Soewarso.2000. Cara-cara Penyampaian Pendidikan Sejarah Untuk Membangkitkan Minat Peserta Didik Mempelajari Bangsanya. DEPDIKNAS

Sudarma, I Komang dan Parmiti, Desak Putu. 2007. Media Pembelajaran. Singaraja. Undiksha

Sudarsono. 2001.Pedoman Pelaksanaan Penelitian Tindakan Kelas (PTK): Bagian kedua. Jakarta: Dirjen Dikti Proyek Pendidikan Tenaga

Sudjana dan Ibrahim.(1989). Penelitian dan Penilaian Pendidikan. Bandung: Sinar Baru Algesindo.

Sudjana, Nana. 2006. Penilaian Proses Belajar Mengajar. Bandung: Remaja Rosdakarya

Suherman dkk,2003, Metedeologi Penelitian Sosial dan Pendidikan .Jakarta:Bumi Aksara

Sumantri, dkk.1999. Strategi Belajar Mengajar. Jakarta: Depdikbud Dirjen Dikti

Supardi, dkk (2009 : 204), Pengertian Tindakan Kelas. Jakarta : Bumi Aksara

Supriantin. 3013. Penerapan Metode Inkuiri Untuk Meningkatkan Aktivitas Siswa Pada Pembelajaran Ipa Di Sd. Artikel. http://download.portalgaruda.org/article.php?article=112357\&val=2338

Suryasubroto. B. 2006. Proses Belajar Mengajar di Sekolah. Jakarta: Rineka Cipta.

Suwatra dkk,(2007:153) Model Pembelajaran Tife Student Teams achivement devision (STAD) sebagai upaya meningkatkan hasil belajar siswa dalam pembelajaran matematika pada siswa kelas IV SD Negeri 1 Tulamben Kecamatan Kubu.Tahun pelajaran 2008 / 2009.Skripsi (tidak diterbitkan). Jurusan Pendidikan guru sekolah dasar, undiksha singaraja

Trianto.(2007) Metode pembelajaran inovatif Berorientasi Kontruksivitis.

Wardani 2004, Penerapan Beberapa Jenis Media Belajar Dalam Pelajaran Matematika Kelas III di Sekolah Dasar No 2 Bulian,Kecamatan Kubutambahan Kabupaten Buleleng.tahun ajaran 1998 / 1999. Sekripsi (tidak diterbitkan). Jurusan teknologi pendidikan, STKIP Singaraja.

Zainudin, (1988:24). Media Intruksional Edukatif.Jakarta: Rineka Cipta. 